\title{
Examining of biology subjects in the science textbook for grade 7 regarding scientific content
}

\author{
Mehmet Yilmaz \\ Gazi University, Faculty of Education, Ankara, Turkey, fbmyilmaz@gmail.com \\ Ertunç Gündüz \\ Hacettepe University, Faculty of Science, Ankara, Turkey, ertuncg@hacettepe.edu.tr \\ Osman Çimen \\ Gazi University, Faculty of Education, Ankara, Turkey, osman.cimen@gmail.com \\ Ferhat Karakaya \\ Kahramanmaraş Sütçüimam University, Faculty of Education, Kahramanmaras, Turkey, \\ ferhatk26@gmail.com
}

\begin{abstract}
For students, textbooks are a source of knowledge and an important learning material. For this reason, textbooks must contain appropriate content. In this research, our aim was to examine of biology subjects on secondary school $7^{\text {th }}$ grade science textbook in terms of scientific content. The data were analyzed using document analysis. Based on criteria such as the book's scientific content, knowledge deficiency, erroneous information and misrepresentations, three experts in the field of biology were assigned the responsibility of reviewing the textbook. The findings of the research, categorized based on the chapters and units of the textbook included a discovery of scientific flaws, insufficient explanations on topics such as "Systems of the Body", "Force and Energy", "Human’s relationship with the environment" and various other errors regarding the assessment questions. Recommendations therefore included a review of the said textbook in order to correct all such errors.
\end{abstract}

Keywords Text book, text book evaluation, scientific content, science course, biology,

\section{7. sınıf fen bilimleri ders kitabı biyoloji konularının bilimsel içerik incelemesi}

ÖZ Öğrenciler için ders kitapları, bilimsel bilginin kaynağı ve önemli bir öğrenim materyalidir. Bu nedenle, ders kitaplarının bilimsel içerik bakımından uygun olması gerekir. Dahası ders kitapları, öğrencilerde kavram yanılgıları oluşturmamalıdır. Bu araştırmada, Ortaokul 7.sınıf Fen Bilimleri ders kitabındaki biyoloji konularının bilimsel içerik bakımından incelenmesi amaçlanmıştır. Veriler doküman analizi ile incelenmiştir. Verilerin bilimsel içerik bakımından değerlendirilmesinde biyoloji alanıyla ilgili uluslararası kitaplar referans olarak kullanılmıştır. Araştırmada, 7. sınıf fen ders kitabı, bilimsel içerik, yetersiz bilgi, hatalı bilgi ve yanlış kavramalar gibi kriterlere göre üç biyoloji uzmanı tarafından incelenmiştir. Araştırma bulguları, ünite ve bölümlere göre kategorize edilerek verilmiştir. Araştırma bulgularında, vücudumuzda sistemler, kuvvet ve enerji, insan ve çevre ilişkileri, ünitelerinde bazı konularda bilimsel yanlışlıklar, ifade eksiklikleri ve ünite bölüm değerlendirme sorularında yanlışlıklar olduğu belirlenmiştir. Bu yüzden 7.sınıf fen bilimleri ders kitabında belirlenen hataların düzeltilmesi önerilmektedir.

Anahtar Ders kitabı, ders kitabı inceleme, bilimsel içerik, fen bilimleri dersi, biyoloji,

Kelimeler

Cite This

Article:

Yilmaz, M., Gündüz, E., Çimen, O. \& Karakaya, F, (2017). Examining of biology subjects in the science textbook for grade 7 regarding scientific content, Turkish Journal of Education. 6(3), 128-142. DOI: 10.19128/turje.318064 


\section{EXTENDED SUMMARY IN ENGLISH}

The development of technology and information in an integrated manner has led to changes in societal expectations of students produced by today's educational system. A good educational system is expected to produce students who can use various ways to access information and find solutions to the problems they encounter. In order to adequately respond to these expectations, science education has become the cornerstone of almost every educational system in the world. However, results from both national and international examinations reveal that science education in Turkey is not sufficient in responding to today's students' needs. Following this, Demircioğlu and Geban (1996) strongly recommended that studies aiming to increase the academic achievement of the students in primary and high school level in science courses should be conducted. A modern curriculum, effective teaching methods, techniques and materials are needed in science education in order to help improve the performance and the success rate of the students in examinations on science.

Textbooks are an important teaching material in such an educational system. This is because textbooks provide information about the content of the courses in the curriculum to the students and enable them to work according to their learning pace (Toprak, 1993). According to Ellis (1997), textbooks are an important teaching material that teachers use for the execution of their lessons in the correct, systematic and conceptual framework. Textbooks are an instructional material in which $99 \%$ of all information is transmitted along with the teacher and the writing board (Alkan, 1996). For this reason, it is very important to have certain criteria and qualifications while preparing a textbook (Wolf ve Schave, 1984; Kelly, 1989; Chiappetta, Fillman and Sethna, 1991; Victory and Kellough, 1997). In Turkey, the Ministry of National Education and the Board of Education and Training have identified four basic criteria to be considered in the review of textbooks.

These criteria are as follows:

a. The content of the textbook must comply with the Constitution and the laws,

b. The textbook's content should be scientifically adequate,

c. The content of the textbook should be beneficial to the education and training program,

d. Visual content designs should support learning, and should conform to the developmental characteristics of the students (MEB TTKB, 2013).

The issue of textbooks and the accuracy of their content have been the subject of numerous researches (e.g. Atıcı, Samancı \& Özel, 2007; Aşçı, Özkan \& Tekkaya, 2001; Aycan, Kaynar, Türkoguz \& Arı, 2002; Çapa, 2000; Çepni, Ayvacı \& Keleş, 2001; Çobanoğlu, Şahin \& Karakaya, 2009; Esgi, 2005; Gibson, 1996; Gündüz, Yılmaz \& Çimen, 2016; Güzel \& Adıbelli, 2011; Kearsey \& Sheila, 1999; Köse, 2009; Özay \& Hasenekoğlu, 2007; Ünsal \& Günes, 2002; Ünsal \& Günes, 2003a; Ünsal \& Günes, 2003b) within the field of education.

In the study by Çapa (2000), it was found that textbooks play an effective role in the misrepresentation of knowledge about photosynthesis among 9th grade students. In a similar study, Aşçı et al. (2001) reported that there are misrepresentations of information about respiration in high school and college textbooks. Equally, Özkan (2001) also confirmed that mistakes in textbooks contributed significantly to misrepresentations of knowledge among 7th grade students. In addition, Cobanoğlu et al. (2009) who examined the 10th grade biology textbook's representation of concepts, problem types, visual materials and assessment techniques, recommended that the textbook should be revised. Further, a study by Gündüz et al. (2016), also reported the presence scientific mistakes, inadequate explanations and mistakes in the units and chapters, as well as the assessment questions of some of the topics contained in the 10th grade biology textbook of the Ministry of National Education.

Meanwhile research has shown that the correction of conceptual misrepresentation among students is more difficult than learning new concepts (Atici et al., 2007). This is why researches aimed at examining the content of textbooks particularly in the field of science and their unit-based assessment questions are very critical. Against this background therefore, the present study examined the scientific content of the $7^{\text {th }}$ grade biology textbook used by secondary schools operating directly under the auspices of the Turkish Ministry of National Education. The data were analyzed using document analysis. International books related to the field of biology were used as references for the evaluation of the data in terms of their scientific content. Based on criteria such as the book's scientific content, knowledge deficiency, erroneous information and conceptual misrepresentations, three experts in the field of biology were assigned the responsibility of reviewing the textbook. The findings, categorized according to the 

scientific content

chapters and units of the textbook, revealed that the textbook did not only contain scientific flaws but also, insufficient explanations on topics such as "Systems of the Body", "Force and Energy", "Human’s relationship with the environment" and various other errors regarding the assessment questions. Recommendations therefore included a review of the said textbook in order to correct all such errors and any other that may be observed. It is also expected that the findings of the research will guide the preparation of future textbooks. 


\section{GíRIŞ̧}

Bilgi çă̆ının yaşandığı günümüzde, öğrencilerin karşılaştıkları problemlere çözüm üretebilmeleri, 21.yüzyıl becerilerine sahip olmaları ve ülkeleri için gerekli nitelikli insan gücünü oluşturabilmeleri iyi bir eğitim sistemiyle mümkün olacaktır. Artık bireylerin bilgiyi ezberleyerek tek bir kaynaktan almaları istenmemektedir (Karamustafaoğlu, 2006). Teknolojini ve bilginin entegre bir şekilde gelişmesi, eğitim sistemi içerisinde öğrencilerden beklentilerin de değişmesine neden olmuştur. Bilgiye ulaşmaya yollarını kullanabilen, karşılaştıkları sorunlara çözüm üretebilen öğrencilerin yetiştirilmesi günümüz dünyasının beklentilerindendir. Fen bilimleri eğitimi, bu beklentilerin sağlanacağı eğitim sisteminin temel taşlarındandır. Ancak yapılan ulusal ve uluslararası sınav sonuçları Türkiye'de fen bilimleri eğitiminin yeterli düzeyde olmadığı göstermiştir. Elde edilen başarısız sınav sonuçları, ilköğretim ve lise düzeyinde öğrenim gören öğrencilerin fen derslerindeki akademik başarılarının artırılmasına yönelik çalışmalara önem kazandırmıştır (Demircioğlu ve Geban, 1996). Öğrencilerin fen bilimlerine yönelik sınavlarda başarılarının artması için fen bilimleri eğitiminde, çağdaş bir eğitim programı olmalı, etkin öğretim yöntem, teknikleri ve materyalleri kullanılmalıdır.

Öğretim materyallerinden bir olan ders kitapları, eğitim sisteminin vazgeçilmez unsurlarından biridir. Ders kitapları, öğretim programlarındaki derslerin içeriğiyle ilgili bilgileri öğrencilere sunan; pekiştirme, sınava hazırlama, öğrenme hızına uygun çalışma olanak sağlayan bir ders materyali olarak tanımlanmaktadır (Toprak, 1993).Ayrıca ders kitapları, öğretim programlarında yer alan konulara ait bilgileri planlı ve düzenli bir biçimde inceleyip açıklayan, bilgi kaynağı olarak öğrenciyi dersin hedefleri doğrultusunda yönlendiren ve eğiten temel doküman (Ünsal ve Güneş, 2002) olarakta tanımlanmaktadır. Öğretim sürecinde önemli bir parçayı oluşturması hem öğretmenlerin hem de öğrencilerin beklentilerinin olması, ders kitaplarının üstlenmiş olduğu misyonu ortaya koymaktadır (OganBekiroğlu, 2007). Ellis (1997)'e göre ders kitapları, öğretmenlerin doğru, sistematik ve kavramsal çerçevede derslerinin yürütmeleri için kullandıkları önemli bir öğretim materyalidir. Ders kitapları, öğretmen ve yazı tahtasıyla beraber tüm bilgilerin \%99'unun iletildiği bir öğretim materyali olarak değerlendirildiğinde (Alkan, 1996), bu materyallerin hazırlanırken belli kriter ve nitelikleri taşıması oldukça önemlidir (Wolf ve Schave,1984; Kelly,1989; Chiappetta, Fillman ve Sethna, 1991; Victory ve Kellough,1997). Nitekim ülkemizde, Millî Eğitim Bakanlığı, Talim ve Terbiye Kurulu Başkanlığ 14 Ocak 2013 tarih ve 27040 sayılı karar ile taslak ders kitaplarının incelenmesinde değerlendirmeye esas olan dört temel kriter belirtmiştir.

Bu kriterler: a. İçeriğin Anayasa ve kanunlara uygunluğu, b. İçeriğin bilimsel olarak yeterliliği, c. İçeriğin eğitim ve öğretim programının kazanımlarını gerçekleştirme yeterliliği, d. Görsel tasarımın ve içerik tasarımının, öğrenmeyi destekleyecek nitelikte olması ve öğrencilerin gelişim özelliklerine uygun olmalı (MEB TTKB, 2013).

Konu ile ilgili alan yazın incelendiğinde, kurumlarda öğretim materyali olarak kullanılan ders kitapların irdelendiği çalışmaların (Gibson, 1996; Kearsey ve Sheila, 1999; Çapa, 2000; Aş̧̧ı, Özkan ve Tekkaya, 2001; Çephi, Ayvacı ve Keleş, 2001; Aycan, Kaynar, Türkoguz ve Ar1, 2002; Ünsal ve Günes, 2002; Ünsal ve Günes, 2003a; Ünsal ve Günes, 2003b; Esgi, 2005; Özay ve Hasenekoğlu, 2007; Atıc1, Samancı ve Özel, 2007; Çobanoğlu, Şahin ve Karakaya, 2009; Köse, 2009; Güzel ve Adıbelli, 2011; Yeniterzi ve Işıksal-Bostan,2015; Gündüz, Yılmaz ve Çimen, 2016) olduğu görülmektedir.

Öğrenciler ders kitapları, bilimsel bilginin kaynağı ve bütün bilimlerin kendisinden tecrübe edinilebileceği bir araç olarak görmektedir (Soong ve Yager, 1993). Bu nedenle hazırlanan ders kitaplarının bilimsel içerik bakımından uygun olması ve öğrencilerde kavram yanılgılarını oluşturmaması gerekmektedir (Gündüz ve ark., 2016). Ancak yapılan bazı çalışmalar ders kitaplarında kavram yanılgılarının ve bilimsel olarak yanlış bilgilerin olduğunu göstermiştir.

Çapa (2000) tarafından yapılan çalışmada, 9.sınıf öğrencilerinin fotosentez konusunda kavram yanılgılarının oluşmasında ders kitaplarının etkili olduğunu belirlenmiştir. Benzer bir çalışmada Aşçı ve ark. (2001) solunum konusunda lise ve üniversite kitaplarında kavram yanılgılarının olduğunu belirtmiştir. Özkan (2001) tarafından yapılan araştırma sonucunda, 7. sınıf öğrencilerinde bulunana kavram yanılgılarının sebepleri arasında ders kitaplarında yer alan hatalardan kaynaklandığını belirlenmiştir. Cobanoğlu ve ark (2009) yaptıkları araştırmada 10. Sınıf biyoloji ders kitabını; kavram yanılgıları, sorun tipleri, görsel materyaller ve ölçme değerlendirme teknikleri bakımından incelemiş ve ders kitabının revize edilmesi gerektiğini belirlemiştir. Gündüz ve ark. (2016) tarafından çalışma 
sonucunda, MEB 10.sınıf Biyoloji ders kitabında yer alan bazı konularda bilimsel yanlışlıklar, ifade eksiklikleri ve ünite bölüm değerlendirme sorularında yanlışlıklar olduğu belirlenmiştir.

Kavramların tanımlamasında yapılan hatalar öğrencilerde düzeltilmesi zor olan kavram yanılgılarına neden olmaktadır (Atıcı ve ark., 2007). Araştırmalar, öğrencilerde oluşan kavram yanılgılarının giderilmesinin yeni kavramlar öğrenilmesinden daha zor olduğunu göstermiştir (Atıcı ve ark., 2007). $\mathrm{Bu}$ nedenle, yapılan çalışmalar ders kitaplarında yer alan kavram yanılgılarının, bilimsel açıdan yanlış verilmiş kavramların, bilgilerin ve soruların tespit edilmesinin gerektiğini göstermiştir. Ĕger fen bilimleri ders kitaplarında yer alan yanlış kavramların ortaya çıkartılmazsa, öğrenciler çevrelerinde olan olayları, sahip oldukları yanlış kavram ve kavram yanılgıları çerçevesinde açıklamaya çalışacaklardır (Büyükkasap ve Samancı, 1998). Ayrıca hatalı bilgilerin öğretilmesi ilerleyen eğitim hayatlarında öğrencilerde düzeltilmesi zor kavramsal yanılgıların oluşmasına neden olacaktır. Ancak alanyazın incelendiğinde ortaokul 7.sınıf fen bilimleri ders kitaplarında yer alan konuların bilimsel içerik bakımından incelenmediği belirlenmiştir. Bu noktadan hareketle araştırmadan elde edilen bulguların hem varolan ders kitaplarının bilimsel içerik bakımından düzenlenmesine hem de yeni hazırlanacak olan temel ders kitabı çalışmalarına ışık tutması beklenmektedir.

\section{Araştırmanın amacı}

$\mathrm{Bu}$ araştırmada, Ortaokul 7.sınıf Fen Bilimleri ders kitabında yer alan biyoloji konularının bilimsel içerik bakımından incelenmesi ve 7. sınıf fen bilimleri ders kitabında yer alan konularda belirlenen bilimsel içerik bakımından yanlışların düzeltilmesi amaçlanmıştır.

\section{YÖNTEM}

\section{Araştırmanın Modeli}

Ortaokul 7.sınıf Fen Bilimleri Ders Kitabının bilimsel içeriğinin doküman analizi yapılmıştır.

\section{Evren ve Örneklem}

Çalışmanın örneklemini Talim ve Terbiye Kurulu Başkanlı̆̆ı'nın 30.11.2015 tarih ve 92 sayılı (ekli listenin 125'inci sırasında) kararıyla 2016-2017 öğretim yılından itibaren 5 (beş) yıl süreyle ders kitabı olarak kabul edilen MEB Ortaokul 7. Sınıf Fen Bilimleri Ders Kitabı oluşturmaktadır. Kitapta biyoloji alanı kapsamında iki ünite yer almaktadır: 1. Vücudumuzdaki Sistemler, 2. İnsan ve Çevre İlişkileri. Ayrıca Kuvvet ve Hareket Ünitesinde yer alan balıklar ve basınç ilişkisine ait örnek te incelenmiştir.

\section{Verilerin Analizi}

MEB Ortaokul 7. Sınıf Fen Bilimleri Ders Kitabı'nda yer alan biyoloji alanıyla ilgili iki ünite bilimsel içerik bakımından üç alan uzmanı tarafından doküman analizi yapılarak incelenmiştir. Bilimsel içeriğin değerlendirilmesinde Dünya genelinde yaygın olarak kullanılan ve kabul gören güncel Campbell Biyoloji (Reece, Urry,Cain, Wasserman, Minorsky ve Jackson, 2013), Yaşam Biyoloji Bilimi (Sadava, Hillis, Heller ve Berenbaum 2014), Deniz Yaşamı Biyolojisine Giriş (Morrissey ve Sumich, 2016), Guyton ve Hall Tibbi Fizyoloji (Hall, 2017), Elements of Ecology (Smith veSmith, 2009), Ekolojinin Temel İlkeleri (Odum ve Barret, 2008), Ecology (Krebs, 2009), Biological Science (Freeman, 2011), Campbell Essential Biology (Simon, Dickey, Hogan ve Reece, 2017), Ecology Concepts and Appications (Molles, 2005), Introduction to Environmental Engineering (Davis ve Cornwell, 2008), Life on Earth (Audesirk, Audesirk ve Byers, 2006), Raven Bitki Biyolojisi (Eichorn ve Evert, 2016), Bitki Fizyolojisi (Teiz ve Zeiger, 2007), Natural Resource Conservation (Chiras ve Reganold, 2005) ve İnsan Anatomisi ve Fizyolojisine Giriş (Solomon, 2003) eserleri bilimsel kaynak olarak kullanılmıştır. Bir ifadenin neden hatalı olduğu, bu eserlerdeki ilgili konular incelenerek doğru şekliyle birlikte açıklanmıştır. İnceleme sonucunda tespit edilen bilimsel hatalar ve hatalarla ilgili açıklamalar eserlerdeki sayfa numaralarıyla birlikte her ünite için hazırlanan tablolarda verilmiştir.

\section{BULGULAR}

Bu bölümde araştırmada ulaşılan bulgular sunulmuştur. Araştırmada, Ortaokul 7.sınıf Fen Bilimleri ders kitabında "Vücudumuzdaki Sistemler Ünitesi" incelenmiş ve elde edilen bulgular Tablo 1'de verilmiştir. 
Tablo 1.

Vücudumuzdaki sistemler ünitesinde belirlenen bilimsel hatalar

\begin{tabular}{ccc}
\hline $\begin{array}{c}\text { Sayfa } \\
\text { No }\end{array}$ & Hatalı veya Tartışmalı İfade & Doğru Açıklama \\
\hline
\end{tabular}

Kalın bağırsak: Besinlerin içerisindeki vitamin, su ve mineraller sindirime uğramadan burada emilerek kana geçer.
Amino asitler, küçük peptidler, vitaminler ve çoğu glukoz molekülünün yer aldığı diğer besin maddeleri, derişim eğimlerine karşı olarak villustaki epitel hücrelerinin içerisine pompalanır (Reece vd, 2013: s.888). Kalın bağırsak içerisine giren kimüs içerisindeki kullanılabilir besin maddelerinin çoğu alınmıştır; fakat çok miktarda su ve inorganik iyonları içerir. Su ve iyonlar, kalın bağırsakta emilir (Sadava vd. 2014: s.1083).

Vitaminlerin emiliminin kalın bağırsakta olduğunun kabul edilmiş olması öğrencilerde kavram yanılgılarına neden olabilir. Mekanik sindirim, farklı şekillerdeki dişlerin kesme, parçalama ve ezme işlevleri sonucunda besinin yüzey alanının genişletilmesi ve daha küçük parçalarına ayrılması ile başlar (Reece vd, 2013: s.883). Sindirim çoğunlukla çiğneme gibi mekanik bir süreçle başlar. Mekanik sindirim, besini daha küçük parçalarına ayırarak, enzimlerin kimyasal sindirimine hazır hale getirir (Simon vd, 2017: s.477). Safra tuzları, yağ damlacıklarının birbirine yapışmasını önleyerek yüzeyini genişletir (Sadava vd. 2014: s.1082). Kitaptaki algı ince bağırsakta safranın yağlar üzerindeki fiziksel etkisi üzerinedir. Oysa açıklamalarda görüldüğü gibi bütün besinler ağızda ve sindirim kanalının her yerinde mekanik etkiye maruz kalmaktadır.

Kitabın bu sayfasında sadece ağı, mide ve ince bağırsakta fiziksel sindirimin olduğu kabul edilmiştir.

Mekanik faaliyet, besinleri sindirim kanalı boyunca hareket ettirir ve sindirime yardım eder. Bir lokma yemek borusuna girer girmez, hem yer çekimi sayesinde ve hem de peristalsis adı verilen kas kasılma dalgaları sayesinde mideye doğru hareket ettirilir. Bu şekildeki peristalsis, besini sindirim kanalı boyunca ağızdan anüse doğru hareket ettirir (Sadava vd, 2014: s.1078). Yemek borusu boyunca çok sayıda basit ve bileşik muköz bezler bulunur. Bu salgılar esas olarak yutma sırasında kayganlaştırmayı sağlar (Hall, 2017: s.809 ve 821).

Kitaptaki ifadelerde midede proteinlerin sindiriminde çok sayıda enzimin işlev gördüğü algısı bulunmaktadır.

Midede proteinlerin sindirimi pepsin enzimi tarafindan gerçekleştirilir. Midenin şef hücreleri tarafından üretilen pepsinojen ile parietal hücreleri tarafindan üretilen $\mathrm{HCl}$, mide boşluğuna salgılanır. $\mathrm{HCl}$, pepsinojeni pepsine dönüştürür (Reece vd., 2013: s.885; Simon vd., s.480; Sadava vd., 1083; Hickman vd.,2016: s.701).

"Yağlar ince bağırsaklardan emilerek kana karışır" ifadesi bilimsel olarak hatalıdır. 6. Sınıf konularında lenf dolaşımı bilindiği için yağların ince bağırsaktan lenf sistemine emildiği belirtilmelidir. Çoğu besin maddesinin bağırsağı terk etmesi kan yoluyla olursa da yağ sindiriminin bazı ürünleri (trigliseritler) farklı bir yol izler (Reece vd., 2013: s.888). Yağ damlacıkları, lakteallerden lenf sistemine girer ve sonunda gögüs kanalı yoluyla kan dolaşımına geçer (Hickman vd.,2016: s.704). Yağ asitleri ve monogliseritler epitel hücrelerine girdikten sonra, yeniden trigliseritleri oluştururlar ve esas olarak şilomikronların içinde taşınarak göğüs lenf kanalı yoluyla dolaşıma dökülürler (Hall, 2017: s.841). 
"Besinlerin sindirilmesiyle vücutta birtakım atık maddeler oluşturulur. Bu atık maddeler boşaltım sistemini oluşturan yap1 ve organlarca vücuttan uzaklaştırılır."

"Karaciğer, proteinlerin sindirimi ile oluşan zararlı bir maddeyi daha az zararlı olan üreye çevirir.”
Besinlerin sindirilmeyen ve emilimi yapılmayan kısmı dışkıyı oluşturur (Reece vd., 2013: s.889). Kalın bağırsak, sindirilememiş kalıntıları bir araya getirir ve suyu geriye emerek katı veya yarı katı dışkıyı oluşturur; dışkı, dışkılama yoluyla vücuttan uzaklaştırılır (Hickman vd., 2016: s.704). Dışkı oluşumu ve dışkılama bir boşaltım değildir. Bu öğrencide kavram yanılgısına yol açar.

Boşaltım, hücrelerde oluşan metabolik atıkları (üre, karbon dioksit gibi) uzaklaştırarak, doku sıvısının hacmini ve bileşimini belirli sınırlar içerisinde tutar (Sadava vd., 1039, 1091-1094; Hickman vd., 2016: s.659).

Proteinlerin sindirimi sonucu amino asitler oluşur. Amino asitler zararlı değildir. Bu ifadede azotlu metabolik atıklar anlatılmak istenmiş, ancak bu haliyle yanlış anlama ve öğrenmelere neden olacağı düşünülmektedir.

Amino asitler hücrede enerji elde etmede yakıt olarak kullanıldığında metabolik olarak amonyak oluşur (Sadava vd., 2014: s.1095). Omurgalı karaciğerinde üretilen üre, amonyakla karbon dioksiti birleştiren bir metabolik döngünün ürünüdür (Reece vd., 2013: s.958; Hall, 2017: s.879).

Omurgalı çevresel sinir sisteminin çıktı bileşenleri iki işlevsel birime ayrılır: motor sistem ve otonom sinir sistemi. Otonom sinir sistemi, düz kasları, kalp kaslarını ve bazı sistemlerin bezlerini kontrol ederek iç ortamı düzenler. Otonom sinir sistemi, birçok vücut organı üzerinde birbiriyle ters etkiye sahip iki grup nörondan oluşur. Parasempatik olarak adlandırılan bir grup, vücuda enerji sağlayan ve depolatan etkinlikleri ("dinlen ve sindir") tetikler. Otonom sinir sistemindeki diğer grup olan sempatik sistem, tersi etkiyle, vücudu dövüşme veya kaçma ("savaş veya kaç") gibi yoğun enerji harcatan etkinliklere hazırlar. Motor sistemin nörönları, başlıca dış uyartılara tepki olarak iskelet kaslarına uyarı taşırlar (Simon vd., 2017: s.582). İnsanda beyinden 12, omurilikten (boyun, sırt, bel, sağrı ve kuyruk kısımlarından) ise toplam 31 çift sinir çıkar (Solomon, 2003: s.109-111).

Şekilde çevresel sinir sistemine ait sinirlerin sadece beyin ve omuriliğin son (kuyruk) kısmından çıktığı gösterilmiştir. Öğrencide yanlış anlamalara neden olmamak için omuriliğin diğer kısımlarından da sinirlerin çıktığının gösterilmesi ayrıca bir organı iki farklı şekilde etkileyen sinirlerin (sempatik ve parasempatik) şeklin sağ ve sol tarafina çizilerek verilmesi uygun olacaktır. Şekilde beyinden çıkan bir sinirin hem göze hem de tükrük bezlerine gittiği görülmektedir. Gerçekte böyle bir sinir yoktur. MEB 7.sınıf düzeyinde de olsa şekiller bilimsel doğruları yansitmalıdır.

Bu şekilde beyin olarak vurgulanan yer talamus veya orta beyin olarak düşünülebilir. Beyin; ön, orta ve arka beyin gibi kısımlardan oluşmaktadır (Reece vd., 2013: s.1068). Şekilde el parmağına raptiye batması ve ele kuş tüyü dokundurulması anlatılmaktadır. Dokunma hissinin ve acının değerlendirildiği merkezler beyin kabuğunda (serebral korteks) bulunur. Dolayısı ile bu gösterim öğrencilerde hem beynin algılanmasında hem de dokunma ve acı duyusunun değerlendirildiği yer ile ilgili yanlış anlamalara neden olabilir. Beyin kabuğu (serebral korteks, algılama, istemli hareketler ve öğrenme için elzemdir. 
Sicak bir maddeye dokunduğumuzda, derimizdeki reseptörler acı hissini alır. Sinirler uyarıyı omuriliğe iletir. Omurilik, kaslarımızın kasılarak elimizin çekilmesini sağlar.
Refleks; bir uyarıya karşı verilen otomatik cevap (Reece vd., 2013: s. 1064) veya beynin katılımı olmaksızın duyu sinirleriyle gelen bilgilerin omurilik kordonunda motor sinirlere çevrilmesi olay1 (Sadava vd., 2014: s. 988) olarak tanımlanabilir. Kitapta tanımlanan olayın refleks olabilmesi için uyaranın bilinç dışı algılanması, örneğin sıcak bir sıvının aniden ele dökülmesi sonucu elin bilinç dışı çekilmesi gerekir.

"Sıcak bir maddeye dokunduğumuzda, derimizdeki reseptörler acı hissini alır." ifadesi bilimsel olarak yanlıştır. Acı hissinin merkezi beyin kabuğunda bulunur. Duyu reseptörleri, uyarıdaki enerjiyi reseptör potansiyeline dönüştürerek, aksiyon potansiyellerinin merkezi sinir sistemine iletimini başlatır. Bu bilgi omurilikten çıkan motor nöronlarla eldeki ilgili kasa iletilir ve el çekilir.

$\mathrm{Bu}$ işlev hipotalamus tarafından yerine getirilir. Omurgalılarda hipotalamus, endokrin ve sinir sistemlerinin ortak çalışmasını sağlamak açısından merkezi bir rol oynar. Beyinde yer alan birkaç endokrin bezden biri olan hipotalamus, tüm vücuttaki sinirlerden ve beyinden bilgi alır. Tepki olarak da, hipotalamus çevresel koşullara uygun olarak endokrin uyarılar başlatır. Hipotalamustan çıkan uyarılar, hemen altında yer alan hipofiz bezine ulaşır (Reece vd., 2013: s. 984).

Bu ifade bilimsel olarak hatalıdır. Büyüme ve gelişme hipofiz tarafından düzenlenir. Tiroit bezinden salgılanan tiroksin hormonu normal kan basıncı, kalp atış hızı ve kas gerginliği düzeyini ayarlar; sindirim ve üreme faaliyetlerini düzenler. Kanda çok fazla ya da çok az tiroit hormonu bulunması, ciddi metabolik bozukluklara yol açabilir. Ayrıca bir başka tiroit hormonu ise kanda kalsiyum düzeyinin ayarlanmasında işlev görür (Reece vd., 2013: s. 986-987).

Burada yanlış bir eşleştirme yapılmıştır. Devlik, akromegali ile aynı anlamda değildir. Çocukluk döneminde fazla büyüme hormonu $(\mathrm{GH})$ salgılanması, vücut oranlarının görece normal kalması, ancak insanın aşırı uzaması (neredeyse $2.4 \mathrm{~m}$ ) olan devliğe (gigantizm) yol açabilmektedir. Erişkin dönemdeki aşırı GH üretimi, hala hormona hassas birkaç kemik dokuda büyümeyi uyarabilmektedir. Hala hassas olan hedef hücreler çoğunlukla yüzde, ellerde ve ayaklarda yer aldığından, sonuç bu ekstremitelerin aşırı büyümesi şeklinde ortaya çıkan akromegalidir (Reece vd., 2013: s. 989).

Adrenalin hormon fazlalığ 1 , feokromasitoma anlamına gelmemektedir. Feokromositomalar, sempatik sinir sisteminin adrenal veya ekstraadrenal yerleşimli ender tümörleridir (Büyükaslan vd, 2014: s.38). Bu bilginin 7.sınıf öğrencilerinin düzeyi için çok yüksek olduğu düşünülmektedir.

$\mathrm{Bu}$ ifade öğrencide yanlış anlamlandırmalara neden olabilir. Aldosteron doğal olarak belirli bir zamanda az, belirli bir zamanda çok salgılanabilir. Ancak, primer aldosteronizm olarak da adlandırılan Conn sendromunda bir veya birden fazla sayıda iyi huylu böbrek üstü bezi tümörleri, büyümesi veya nadiren böbrek üstü bezi kanseri nedeniyle aşırı miktarlarda aldosteron üretilmektedir (Yetişir vd., 2013: s.38). Bu bilginin 7.sınıf öğrencilerinin düzeyi için çok yüksek olduğu düşünülmektedir. 
"Sinirlerin çıktığı kısımda görüntü oluşmadığından bu kısım kör nokta adını alır. Kör noktanın biraz üst kısmında görüntünün ters oluştuğu kısım sarı leke adını alır. Sarı leke üzerinde görme reseptörleri bulunur. Görüntü görme reseptörleri tarafindan algilanir."
Bu ifadede kör noktada neden görüntü oluşmadığ 1

anlatılmamıştır. Ayrıca görüntünün sadece sarı leke üzerinde oluştuğu, reseptörlerin sadece sarı leke üzerinde olduğu algısı oluşmaktadır. İnsan gözünde retina, ışı̆̆ı algılayan fotoreseptör hücreler içerir. En net görüntünün oluştuğu bölge olan sarı benek (sarı nokta veya fovea), merceğin ve korneanın merkeziyle aynı hat üzerinde olmak üzere retinanın merkezinde konumlanmıştır. Fovea, sadece koni reseptörleri içerir; bu, gündüz (gün ışığında) görüş için bir omurgalı özelleşmesidir. "Kör nokta”, optik sinirin retinanın dışına çıktığı bölge olduğundan, fotoreseptör hücreler bulunmaz. Bu nedenle kör nokta üzerine odaklanan 1şık algılanamaz (Simon vd., 2017: s.590-591). Retinanın dışında da çubuk reseptörler bulunur. Gece koşulları altında, görüntünün en net olduğu yer, foveanın merkezinde değil onun kenar kısımlarındadır (Hickman, vd., 2016: s.733).

İç kulağın içi sıvı dolu değildir. Bu ifade öğrenci tarafından yanlış anlamlandırılabilir. Ayrıca, sayfadaki şekilde yarım daire kanalları gösterilmesine karşın, yazılı metinde bu yapıların dengenin sağlanmasında işlev gördüğünden bahsedilmemiştir. İç kulak şakak (temporal) kemiğinin belli bir parçasının içine yerleşmiştir. Bu kısım kemik labirenttir. Kemik labirentin içinde perilenf, zar labirentin içinde endolenf sıvısı bulur (Solomon, 2003: s.123). İç kulak, içi sıvı dolu odacıklardan oluşmuştur; bunlar arasında dengenin sağlanmasında işlev gören yarım daire kanalları ve işitmede işlev gören kıvrılmış bir kemik odacık olan kohlea (Latincede "salyangoz" demek) yer alır (Reece vd., 2013: s.1091).

Memelilerin iç kulağındaki denge organı (vestibüler sistem), kemik olan üç tane yarım daire kanalından, tulumcuk (sacculus) ve kesecik (utriculus) adı verilen iki kemik odacıktan oluşmuştur. Tüm vestibüler sistem, endolenf adı verilen bir sıvı ile doludur. Yarımdaire kanallarındaki endolenf, başınızın pozisyonunu değiştirince hareket eder (Sadava vd., 2014: s.975).

Şekil. Dilin tat almaya duyarlı kısımları ve tat alma hücreleri. "Farklı tatları alan tat tomurcukları dilin farklı bölgelerinde yoğunlaşmıştır. Dilin uç kısmı tatlıya, uca yakın yanları tuzluya, arkaya yakın yanları ekşiye, arka kısmı acıya daha duyarlıdır."

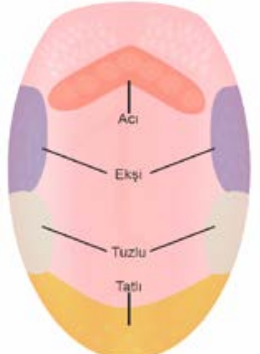

Göz merceğinin yapısındaki bozukluk nedeniyle cisimlerin görüntüsü retinanın önünde oluşur. Yakın görülür, uzak mesafedeki cisimler net görülemez. Bu göz kusuruna miyop denir.
Şekil ve verilen bilgi yaygın olarak yerleşmiş bir kavram yanılgisıdir.

İnsanlar ve diğer memeliler, beş çeşit tadı algılayabilir. Yıllardır birçok araştırmacı, tat alan hücrenin birden fazla çeşitte reseptörü olabileceğini varsaydı. Memelilerde tat alınmasından sorumlu reseptör hücreler, tat tomurcukları şeklinde organize olmuş olan değişime uğramış epitel hücrelerdir; tat tomurcukları, ağız ve dilin değişik bölgelerine yayılmış olarak bulunur.

Dildeki tat tomurcuklarının çoğu, papilla denen meme biçimindeki çıkıntılarla birlikte yer alır. Tat tomurcuklarına sahip dilin herhangi bir bölgesi, beş çeşit tattan herhangi birini algılayabilir. (Böylece, dilin sıklıkla çıkartılan "tat haritası", kesin değildir) (Reece vd., 2013: s.1101-1102).

Temel tat duyuları beş küme halinde gruplandırılabilir. Bunlar ekşi, tuzlu, tatlı, acı ve lezzetli (umami) dir. Yapılan araştırmalar, tat maddesi düşük derişimde iken, her tat tomurcuğunun beş temel tat uyarısından bir tanesine en fazla yanıt verdiğini göstermiştir (Hall, 2017: s.685-687).

Uzağı göremeyen bir göz küresi, normalden uzun olup, uzaktaki cisimleri retinanın üzeri yerine önüne odaklar. Yani miyopluk, göz küresi normalden daha uzun olduğu ve uzaktaki cisimler retinanın önünde odaklandığı zaman ortaya çıkar (Simon vd., 2017: s.591). 
45 kaybettiğinde ise astigmat denilen göz kusuru oluşur.

Soru 1. Yumurta, sindirim sisteminin hangi kısımlarında kimyasal sindirime uğrar?

51 A. Ağız-mide

B. Mide-ince bağırsak

C. Mide- kalın bağırsak

D. Yemek borusu- ince bağırsak

Soru 2. Aşağıdaki besin gruplarından hangisinin kimyasal sindirimi ağıda başlar?

A. Süt ve süt ürünleri

B. Meyve grubu

C. Sebze grubu

D. Karbonhidrat grubu
Bu ifade bilimsel olarak doğru olmayıp, öğrencilerde yanlış öğrenmelere yol açabilir. Astigmatizm, şekli düzgün olmayan mercek veya kornea nedeniyle oluşur. Bu tip bir şekil bozukluğu, 1şığın retina üzerinde bir noktada düzgün birleşmemesine yol açar. Mercek veya korneanın şekil bozukluğu nedeniyle bulanık görme (Simon vd., 2017: s.591).

Yumurtanın bileşiminde su, protein, yağ, karbonhidrat, bazı vitaminler ve mineraller bulunur. İnsanda karbonhidratların sindirimi tükrük amilazı aracılığı ile ağızda başlar. Proteinler mide ve ince bağırsakta, yağlar ise ince bağırsakta kimyasal sindirime uğrar (Reece vd., 2013: s.886). Soru, yumurtanın sadece protein içerdiği düşüncesiyle sorulmuştur. Bu nedenle soru bilimsel ve ölçme tekniği açısından öğrencilerde yanlış ögrenmelere neden olabilir.

Soruda çok sayıda besin, gruplandırılarak resimleriyle birlikte verilmiştir. Ağızda polisakkaritler (nişasta, glikojen) tükrükteki amilaz enzimiyle sindirilmeye başlar (Reece vd., 2013: s.886). Bitki hücreleri gerektiğinde kullanılabilen bir şeker deposu sağlayarak, nişasta depolar. Tohumlar ve yumurtalar depo proteinleri açısından zengindir (Simon vd., 2017: 42-46). Bu soruda $B$ ve $C$ seçeneğinde verilen sebze ve meyve grubu içeriklerinde nişasta da bulunmaktadır. Dolayısı ile onların içeriğindeki nişasta da ağızda sindirilmeye başlar. Bu nedenlerle soru bilimsel olarak ve ölçme tekniği açısından öğrencilerde yanlış öğrenmelere neden olabilir.

Soru 6. Sağlıklı bir insanın gözüne ait kısımlar numaralandırılmıştır. Görüntünün oluştuğu kısım hangi numara ile belirtilmiştir?

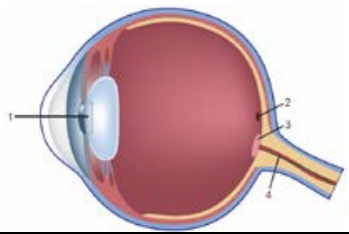

Soru 7. Acı biber yiyen bir kişinin dilinde numaralı

53 kisımlardan hangisi daha yoğun uyarılır?
$\begin{array}{llll}\text { A. } 1 & \text { B. } 2 & \text { C. } 3\end{array}$
D. 4

İnsan gözünde cisimlerin görüntüsü retinadaki sarı benek üzerine düşer. Fotoreseptörlerde meydana gelen aksiyon potansiyeli optik sinir tarafından beynin görme merkezine iletilir. Beyin kabuğundaki görme merkezinde görüntü üç boyutlu olarak algılanır (Simon vd., 2017: s.589-590). Bu açıklama doğrultusunda, soru ölçme tekniği açısından değerlendirildiğinde yanlış algılamalara neden olabilir. Sarı beneğin sorulabilmesi için "Cismin görüntüsü gözde hangi bölgeye düşer?" denilmesi uygundur. Çünkü görüntünün algılanması beyin kabuğundaki görme merkezinde gerçekleşir.

Soruda, dilin tatların iyi alındığı bölgeler şeklinde gruplandırılması, yaygın olarak görülen bir kavram yanılgısını tekrarlamaktadır.

Tat tomurcuklarına sahip dilin herhangi bir bölgesi, beş çeşit tattan herhangi birini algılayabilir. Böylece, dilin sıklıkla çıkartılan "tat haritası", kesin değildir (Reece vd., 2013: s.11011102).

Soru 10. Hangi iki duyu organı arasındaki ilişki daha bağlantılıdır?

A. Görme-koklama

B. Koklama-tatma

C. Dokunma- tatma

D. Dokunma-koklama

Soru kökü açık olmayıp, öğrenciler tüm seçenekleri doğru kabul edebilir. Ölçme tekniği açısından okuyucu, sorunun ne istediğini anlamak zorunda bırakılıyor. Yanıtı B seçeneği olan bu soru "Aşağıdaki hangi iki duyu organında reseptörler benzer şekilde uyarılır" şeklinde sorulabilir.

Bitkilerde nişasta, yăg, protein bulunabilir. İnsan bu besinleri içeren bitkileri yediğinde bu besinleri "aynı şekilde" vücuduna alamaz. Örneğin, bitkilerdeki depo karbonhidrat nişastadır, ancak sindiriminden sonra yapı birimleri olan glikoz kana emilebilir. Hayvanlar, süreklilik gösteren ATP gereksinimini karşılamak için, karbonhidratlar, proteinler ve lipitlerin yer aldığı besin maddelerini, hücresel solunumda ve enerji depolanmasında kullanmak amaciyla yerler ve sindirirler (Reece vd, 2013: s.876). 
81

“Sindirimle besinlerdeki

kimyasal bağ enerjisi açı̆̆a çıkar."
$\mathrm{Bu}$ ifadede kavram yanılgısı bulunmaktadır. Hayvanlar, besindeki proteinleri, karbonhidratları, nükleik asitleri, yağları ve fosfolipitleri doğrudan kullanamadıkları için kimyasal sindirim gereklidir (Reece vd., 2013: s. 880). Besinler öncelikle büyük ve karmaşık moleküller halinde olduklarından, hayvan hücrelerince kullanılamazlar. Vücudun bu besinleri yararlı kılabilmek için parçalaması gereklidir. Yeme, besinlerin alınmasıdır. Sindirim, vücudun besinleri alabileceği ölçüde moleküllerine parçalamaktır. Emilim, küçük besin moleküllerinin sindirim kanalını döşeyen hücreler tarafından alınmasıdır (Simon vd., 2017: s. 94, s.475) Sindirimle besinler yapı birimlerine dönüştürülür. Bu süreç bir hidroliz olup enerji elde edilmez. Enerji, hücrelerde hücre solunumu, oksijensiz solunum ve fermantasyon süreçleriyle elde edilir (Sadava, 2014: s.184).

Tablo 1 incelendiğinde; vitaminlerin emiliminin kalın bağırsakta olduğunun kabul edildiği, yağların fiziksel sindiriminde sadece safranın etkili olduğu, midede proteinlerin sindiriminde çok sayıda enzimin işlev gördüğü, yağların tamamen ince bağırsaklardan emilerek kana karıştı̆̆ı, besinlerin sindirilmesiyle vücutta atık maddelerin boşaltım sistemini oluşturan yapı ve organlarca vücuttan uzaklaştırıldığ1, proteinlerin sindirimi ile azotlu metabolik atıkların oluştuğu şeklinde algılamalara neden olacak ifadelerin bulunduğu görülmektedir.

Ayrıca refleks olayı, endokrin bezlerin işlevleri gibi konularda yanılgıların olduğu saptanmıştır. Feokromasitoma ve Conn sendromu gibi kavramların ise öğrencilerin seviyesinin üzerinde olduğu düşünülmektedir. Refleks, gözde görüntünün oluşması, iç kulağın yapısı ve denge işlevi, dilde tatların algılandığı bölgeler, miyop ve hipermetrop kavramları, besinlerin kimyasal bileşimleri, sindirim, emilme ve besinlerden enerji elde edilmesi konularında öğrencilerde kavram yanılgılarına neden olabilecek ifadelere rastlanmıştır.

Araştırmada, Ortaokul 7.sınıf Fen Bilimleri ders kitabında “Kuvvet ve Enerji Ünitesi” incelenmiş elde edilen bulgular Tablo 2'de verilmiştir.

Tablo 2.

Kuvvet ve enerji ünitesinde belirlenen bilimsel hatalar

Sayfa No Hatalı veya Tartışmalı İfade Doğru Açıklama

Fizik alanındaki "Kuvvet ve Enerji” ünitesi kapsamında balıklarla ilgili verilen bu bilgi bilimsel olarak yanlış olup, öğrencilerde kavram yanılgılarına neden olabilir. Balıkların farklı derinliklerde yaşayabilmesi habitat tercihlerinden, anatomik özelliklerinden ve uyum yeteneklerinden dolayıdır.

Pek çok balıkta suda batmadan kalabilmede işlev gören yüzme kesesi bulunur. Bir alabalık veya turnabalığı, havadan 800 kat daha yoğun bir ortamda, yüzme kesesine hava doldurarak veya

"Balıklar, su içerisinde bulundukları derinliğe bağlı olarak farklı miktarda basınca maruz kalır. Bazı balık türleri yüksek basınca dayanamadıklarından, suyun derin olduğu kısımlarda yaşayamaz." boşaltarak, nötral yüzdürme kuvvetini değiştirmek suretiyle su içerisinde hareketsiz kalabilir. Kemik, kan ve diğer dokuların aksine gaz sıkıştırılabilir ve derinlik değiştikçe balığın hacmi de değişir. Balık daha derinlere gittikçe çevredeki su tarafından uygulanan yüksek basınç, yüzme kesesindeki gazı sıkıştırarak balığın batmazlığını azaltır ve balık batmaya başlar. Balık yukarı doğru yüzerken çevredeki suyun basıncının azalmasından dolayı yüzme kesesindeki gaz genleşir ve balık daha hafifleyerek yukarı doğru çıkar. İçerideki gaz uzaklaştırılmadığı surece yüzme kesesi genişlemeye devam ettiğinden balık gittikçe daha fazla hızlanarak yukarı doğru yükselir (Hickman vd., 2016: s.497 ve 527). Yüzme keseleri sabit yapılar değildir; farklı derinliklerde su basıncının değişmesi ile hacimleri değişir. Yüzme keseleri gaz dolu balıklar 7000 metreden avlanabilmektedir. O derinlikte su basıncını dengelemek için yüzme kesesi içindeki gaz basıncı 700 atmosferdir (Morrissey ve Sumich, 2016: s.361-363). 
Tablo 2’ de, kuvvet ve enerji ünitesinde, sıvı basıncını etkileyen değişkenler başlığı altında; balıkların çoğunluğunda derinlere inme ve yukarıya çıkmada yüzme kesesinin içindeki gaz miktarının değişimiyle dış basınca karşı ayarlama yapabildiğinin dikkate alınmadığı belirlenmiştir.

Araştırmada, MEB Ortaokul 7.sınıf ders Fen Bilimleri kitabında “İnsan ve Çevre İlişkileri Ünitesi”, incelenmiş ve elde edilen bulgular Tablo 3 'de verilmiştir.

Tablo 3.

İnsan ve çevre ilişkileri ünitesinde belirlenen bilimsel hatalar

\begin{tabular}{|c|c|c|}
\hline Sayfa No & Hatalı veya Tartışmalı İfade & Doğru Açıklama \\
\hline 171 & $\begin{array}{l}\text { Biyo-çeşitlilik, bir } \\
\text { ekosistem veya tüm } \\
\text { dünyada bulunan yaşam } \\
\text { formlarının çeşitliliğidir. }\end{array}$ & $\begin{array}{l}\text { MEB 7. Sınıf Fen Bilimleri Dersi Öğretim Programı'nda biyo- } \\
\text { çeşitlilikle ilgili "Biyo-çeşitliliğin doğal yaşam için önemini } \\
\text { sorgular” ve "Biyo-çeşitliliği tehdit eden faktörleri, araştırma } \\
\text { verilerine dayalı olarak tartışır ve çözüm önerileri üretir." } \\
\text { kazanımları bulunmaktadır. Kitapta yapılan tanım biyoçeşitliliği, } \\
\text { sadece tür çeşitliliği yönünde ele almaktadır. } \\
\text { Biyoçeşitlilik kavramı; genetik çeşitlilik, tür çeşitliliği ve } \\
\text { ekosistem çeşitliliğini kapsar. Böylece, biyoçeşitlilik kaybı, } \\
\text { bireysel türlerin akıbetinden çok daha fazlasını kapsar (Simon } \\
\text { vd., 2017: s.426). "Biyoçeşitlilik" terimi çok anlamlıdır. } \\
\text { Biyoçeşitlilik, bir tür içerisindeki genetik varyasyonun derecesi } \\
\text { olarak tanımlanabilir. Ayrıca biyoçeşitlilik belirli bir } \\
\text { komünitedeki tür zenginliği bakımından da tanımlanabilir. Büyük } \\
\text { ölçüde, biyoçeşitlilik ekosistemlerin içindeki ve arasındaki } \\
\text { karmaşı etkileşimler olan ekosistem çeşitliliğini de kapsar } \\
\text { (Sadava vd., 2014: s.1243-1244). }\end{array}$ \\
\hline
\end{tabular}

Tablo 3'de biyoçeşitliliğin sadece tür çeşitliliği anlamıyla ele alındığı görülmüştür. Ünitenin geri kalan kısımlarındaki bilimsel açıklamaların yerinde ve örneklerin konuyu açıklamada yeterli olduğu düşünülmektedir.

\section{TARTIŞMA ve SONUÇLAR}

Araştırmada, Ortaokul 7.sınıf Fen Bilimleri ders kitabında yer alan biyoloji konularının bilimsel içerik bakımından incelenmiştir. Ders kitabında yer alan biyoloji konularındaki bilimsel hatalar belirlenmiş ve gerekli kaynak kitaplar referans gösterilerek doğru bilgiler araştırma bulgularında verilmiştir.

Araştırma bulguları, Ortaokul 7.sınıf Fen Bilimleri ders kitabında yer alan "Vücudumuzdaki Sistemler Ünitesi” ile ilgili vitamin ve yağların geri emilimi mekanizmaları hakkında hataların olduğu belirlenmiştir. Araştırmada, besinlerin (protein, yağ) sindirim mekanizmaları ve proteinlerin vücuttan uzaklaştırma mekanizmaları hakkında hataların olduğu da tespit edilmiştir. Güngör ve Özgür (2009) araştırma bulgularında, öğrencilerin sindirim ve boşaltım sistemi organları arasında yanlış ilişski kurduklarını ve bu durum öğrencilerde didaktik kökenli kavram yanılgılarının oluşmasına neden olduğunu belirlemişlerdir. Benzer şekilde Carvalho, Silva ve Clement'in (2003), Portekiz'deki öğrenciler ile ilgili yaptıkları araştırmanın bulguların da, ders kitaplarında sindirim ve dolaşım sistemi organları arasındaki ilişkinin olmadığı, bu durumunda öğrencilerde öğrenme engeli oluşturduğunu belirlemişlerdir. Clément ve Tunnicliffe (2002) ise araştırma bulgularında, sindirim sisteminin öğrenilmesinde iki temel engelin olduğunu ifade etmiştir. Bu engeller:

1. Sindirim sisteminin bir başlangıcı bir sonu olan, arada hiçbir geçirgenliği olmayan bu nedenle de kana emilimi ile ilgili hiçbir çizime rastlayamadığımız bir tüp olarak tanımlanması

2. Sindirim sisteminde katı besinlerin sindiriminin gerçekleştiğinin düşünülmesi (Clément ve Tunnicliffe, 2002).

Tekkaya ve ark. (2000) araştırma bulgularında, biyoloji öğretmen adaylarının sindirim, solunum, boşaltım sistemi, enzim konularında kavram yanılgılarının olduğunu vurgulamışlardır. Kabapınar (2007) araştırma bulgularında, ilköğretimden lisans düzeyine kadar öğrencilerde kavram yanılgılarının olduğunu ve bunun önemli bir sebebinin ders kitaplarından kaynaklandığını belirtmiştir. Fransa'da yazılan yeni kitaplarda ise başta bağırsaklar olmak üzere sindirim sistemi organlarının şekilleri eklenmiş 
ve sonrasında öğrencilerin kavram yanılgılarında azalmalar olduğu tespit edilmiştir (Carvalho, Silva ve Clement, 2007).

Ayrıca araştırmada, duyu organları, görme olayı, görme kusurları, refleks ve endokrin bezlerle ilgili hataların olduğu ortaya çıkartılmıştır. Feokromasitoma ve Conn sendromu gibi kavramların ise öğrencilerin seviyesinin üzerinde olduğu düşünülmektedir. Tekkaya, Çapa ve Y1lmaz (2000) ve Gündüz ve ark. (2016) yaptıkları araştırmada öğrencilerin biyolojinin çeşitli konularında öğrenme güçlükleri yaşadıklarını belirlemişlerdir. Ecevit ve Şimşek (2017) kavram öğretiminde öğretmenlerin en çok zorlandığ1 biyoloji konular arasında sistemlerin olduğunu belirtmişlerdir. Guesne (1985), Çökelez ve Yaşar (2015) araştırma bulgularında, öğrencilerin görme olayı ile ilgili kavram yanılgılarının olduğunu belirlemişlerdir. Bu çalışmalar, araştırmanın bulgularını ve önemini desteklemektedir.

Araştırma bulguları, Ortaokul 7.sınıf Fen Bilimleri ders kitabında yer alan "Kuvvet ve Enerji Ünitesi", ile ilgili sıvı basıncını etkileyen değişkenler başlığı altında hataların olduğu belirlenmiştir. Balıkların çoğunluğunda derinlere inme ve yukarıya çıkmada yüzme kesesinin içindeki gaz miktarının değişimiyle dış basınca karşı ayarlama yapabildiğinin dikkate alınmadığı anlaşılmaktadır.

Araştırma bulguları, Ortaokul 7.sınıf Fen Bilimleri ders kitabında yer alan "İnsan ve Çevre İliş̧kileri Ünitesi" ile ilgili biyoçeşitliliği sadece tür çeşitliliği anlamında değerlendirilmesinin hatalı olduğu belirlenmiştir. Çobanoğlu ve ark. (2009) araştırma bulgularında, 10.sınıf biyoloji test kitaplarında ekoloji ile ilgili konularda hataların olduğunu belirlemişlerdir. Benzer bulgular Tekkaya ve ark. (2000) tarafından da belirlenmiştir. Bu sonuçlar araştırmanın bulgularını desteklemektedir.

\section{Öneriler}

Yapılan çalışmalar, ders kitaplarında önemli hataların olduğu ve bunların öğretim materyali olarak kullanılmasının yanlış öğrenmelere neden olacağını göstermiştir. Bu nedenle gerek ders kitaplarının gerekse öğretmenlerin bilimsel hatalardan arındırılmış bilgileri aktarması gerekmektedir. Araştırmada elde edilen sonuçlar doğrultusunda aşağıdaki önerilere yer verilmiştir;

Ortaokul 7.sınıf Fen Bilimleri ders kitabındaki yer alan vücudumuzda sistemler, kuvvet ve enerji, insan ve çevre ilişkileri üniteleri ile ilgili öğrencilerde oluşan kavram yanılgıların belirlenmesine yönelik araştırmalar alanyazın için önemli olacaktır.

Yeni araştırmalarda Ortaokul 7.sınıf fen bilimleri ders kitabındaki fizik ve kimya konularının incelenmesi, ders kitabında yer alan tüm konuların bilimsel içerik bakımından doğruluğunu sağlayacaktır.

Öğretmenlerin, ders ve yardımcı kitapların yanında Dün ya genelinde yaygın olarak kullanılan güncel akademik kitapları da takip etmeleri yararlı olacaktır.

Ders kitapları hazırlanırken TTKB tarafından yazarlara kavram yanılgılarıyla ilgili bilgilerin verilmesi yerinde olacaktır.

TTKB tarafından hazırlatılan ve komisyonlarda başarılı bulunan kitapların alanda uzman bilim insanları tarafından yeniden incelenmesi sağlanmalıdır.

TTKB, hali hazırda okutulan MEB kitaplarında alan uzmanları tarafından belirlenen hataların tüm paydaşlara iletimini sağlamalıdır.

\section{KAYNAKLAR}

Alkan, C. (1996). Eğitim Teknolojisi. Ankara: Atilla Kitabevi.

Aşçı, Z., Özkan, Ş., Tekkaya, C. (2001). Students’ misconceptions about respiration. Eğitim ve Bilim, 26(120), 2936.

Atici, T., Samancı, N.K. ve Özel, Ç.A. (2007). İlköğretim fen bilgisi ders kitaplarının biyoloji konuları yönünden eleştirel olarak incelenmesi ve öğretmen görüşleri. Türk Eğitim Bilimleri Dergisi, 5(1), 115-133.

Audesirk, T., Audesirk, G. ve Byers, B.E. (2006). Life on Earth. Pearson Prentice Hall, 643p., USA.

Aycan, Ş., Kaynar, Ü. H., Türkoğuz, S. ve Arı, E. (2002). İlköğretimde kullanılan fen bilgisi ders kitaplarının bazı kriterlere göre incelenmesi. V. Ulusal Fen Bilimleri ve Matematik Eğitimi Kongresi (16-18 Eylül), Ankara, Bildiriler, 1, 246-252.

Büyükkasap, E. ve Samancı, O. (1998): İlköğretim öğrencilerinin ışık hakkındaki yanlış kavramları. Gazi Üniversitesi Kastamonu Ĕ̈itim Fakültesi Dergisi, 4(5), 109-120.

Carvalho, G.S., Silva, R. ve Clément, P. (2007). Historical analysis of portuguese primary school textbooks (19202005) on the topic of digestion. International Journal of Science Education, 29(2), 173-19. 
Carvalho, G.S., Silva, R. ve Clément, P. (2003). Epistemological and didactical learning obstacles identified in Portuguese primary school pupils (Synopsis), in ESERA 2003: Research and the Quality of Science Education. ESERA, Noordwijkerhout, CD.

Chiappetta, E.L., Fillman, D.A. ve Sethna, G.H. (1991). A method to quantity major of scientific literacy in science textbooks. Journal of Research In Science Teaching, 28(8),713-725.

Chiras, D.D. ve Reganold, J.P. (2005). Natural Resource Conservation, Pearson Education, Inc., 644p., USA.

Clément, P. ve Tunnicliffe, S.D. (2002). Digestion / Circulation / Excretion: First results on the ontogenesis of the continuous tubing conception in U.K. pupils. Poster in Meeting ERIDOB, ENFA, Toulouse.

Cobanoglu, E., Sahin, B. ve Karakaya, C. (2009). Examination of thebiologytextbookfor 10th grades in high school education and theideas of thepre-service teachers. Procedia - Social and Behavioral Sciences, 1(1), 25042512.

Çapa, Y. (2000). An analysis of 9th grade students' misconceptions concerning photosynthesis and respiration in plants, Yayımlanmamış yüksek lisans tezi, Orta Doğu Teknik Üniversitesi, Ankara.

Çepni, S., Ayvacı, H. Ş., ve Keleş, E. (2001). Fizik ders kitaplarını değerlendirme ölçeği geliştirmek için örnek bir çalışma. Milli Ë̆gitim, 152, 27-33.

Çökelez, A. ve Yaşar, S. Ç. (2015). 6. sınıf öğrencilerinin 'görüntü kavramı' ile ilgili kavramsal öğrenmelerinin incelenmesi. Electronic Turkish Studies, 10(14), 159-180.

Davis, M.L. ve Cornwell, M.L. (2008). Introduction to environmental engineering, Mc-Graw Hill International Edition, 1008p., USA.

Demircioğlu, H. ve Geban, Ö. (1996). Fen bilgisi öğretiminde bilgisayar destekli öğretim ve geleneksel problem çözme etkinliklerinin ders başarısı bakımından karşılaştırılması. Hacettepe Üniversitesi Eğitim Fakültesi Dergisi, (13),183-185.

Ecevit, T. ve Şimşek, P. Ö. (2017). Öğretmenlerin fen kavram öğretimleri, kavram yanılgılarını saptama ve giderme çalışmalarının değerlendirilmesi. İlköğretim Online, 16(1),129-150.

Eichorn, S.E. ve Evert, R.F. (2016). Raven bitki biyolojisi. (İ. Türkan, Çev.). Ankara, Palme Yayıncılık.

Ellis, R. (1997). The empirical evaluation of language teaching materials. ELT Journal 51,36-42.

Eşgi, N. (2005). İlköğretim 5. sınıf bilgisayar ders kitaplarının görsel tasarım ilkelerine göre değerlendirilmesi. Milli Eğitim Dergisi, 165, 34-36.

Freeman, S. (2011). Biological science, Pearson Benjamin Cummings, 1127p, USA.

Gibson, D.J. (1996). Textbook misconceptions: The climax concept of succession. The American Biology Teacher, 58(3), 135-140.

Guesne, E. (1985). Light. In R. Driver, E. Guesne ve A. Tiberghien (Eds.), Children's ideas in science. Philadelphia: Open University Press.

Gündüz, E., Yılmaz, M. ve Çimen, O. (2016). MEB Ortaöğretim 10. sınıf biyoloji ders kitabının bilimsel içerik bakımından incelenmesi. Bayburt Ĕgitim Fakültesi Dergisi, 11(2), 414-430.

Güngör, B. ve Özgür, S. (2009). İlköğretim beşinci sınıf öğrencilerinin sindirim sistemi konusundaki didaktik kökenli kavram yanılgılarının nedenleri. Necatibey Eğitim Fakültesi Elektronik Fen ve Matematik Eğitimi Dergisi, 3(2), 149-177.

Güzel, H. ve Adibelli, S. (2011). 9. sınıf fizik ders kitabının eğitsel, görsel, dil ve anlatım yönünden incelenmesi. Selçuk Üniversitesi Sosyal Bilimler Enstitüsü Dergisi, (26), 201-216.

Hall, J.E. (2017). Guyton ve Hall Tıbbi Fizyoloji. (B. Ç. Yeğen, Çev.). Ankara, Güneş Tıp Kitabevleri.

Hickman, C.P., Roberts, L. ve Larson, A. (2016). Integrated principles of zoology, Mc-Graw Hill International Edition, 871p., USA.

Karamustafaoğlu, O. (2006). Fen ve teknoloji öğretmenlerinin öğretim materyallerini kullanma düzeyleri: Amasya ili örneği. Atatürk Üniversitesi Bayburt Eğitim Fakültesi Dergisi, 1(1), 90-101.

Kabapınar, F. (2007). Öğrencilerin Kimyasal Bağ Konusundaki Kavram Yanılgılarına İlişkin Literatüre Bir Bakış I: Moleküliçi Bağlar. Mili Ĕ̆itim Dergisi, 176, 18-35.

Kearsey, J. ve Sheila, T. (1999). How useful are the figures in school biology textbooks? Journal of Biological Education, 33(2), 87-94.

Kelly, A.V. (1989). Curriculum. Theory and practice. London.Paul Chapman Publishing Ltd.

Köse, E. Ö. (2009). Biyoloji 9 ders kitabında hücre ile İlgili metinlerin okunabilirlik düzeyleri. Journal of Arts and Sciences, 12, 141-150.

Krebs, J. C. (2009). Ecology (Sixth Edition), Pearson International Edition, Publishing as Benjamin Cummings, 655 p., USA.

MEB Talim ve Terbiye Kurulu Başkanlığı [MEB TTKB]. (2013). Taslak kitap incelemede değerlendirmeye esas olacak kriterler konulu 27040 sayll, 14.01.2013 tarihli yazl. Ankara: MEB

Molles, C.M. 2005: Ecology (Concepts and Appications), McGraw-Hill, 622 p., USA.

Morrissey, J.F. ve Sumich, J.L. (2016). Deniz yaşamı biyolojisine giriş. (M. Karataş, H.H. Atar, Çev.). Ankara, Nobel Yayıncilik.

Odum, E.P. ve Barrett, G.W. (2008). Ekoloji’nin temel ilkeleri. (K. Işık, Çev.). Ankara., Palme Yayıncılık., 598 
Ogan-Bekiroğlu, F. (2007). To what degree do the currently used physics textbooks meet the expectations? Journal of Science Teacher Education, 18, 599-628.

Özay, E. ve Hasenekoğlu, G. (2007). Lise-3 biyoloji ders kitaplarındaki görsel sunumda gözlemlenen bazı sorunlar. Türk Fen Ë̆itimi Dergisi, 4(1): 80-91.

Özkan, Ö. (2001). Remediation of seventh grade students misconceptions related to ecological concepts through conceptual change approach. Yayımlanmamış yüksek lisans tezi, Orta Doğu Teknik Üniversitesi, Ankara.

Reece, J.B., Urry, L.A., Cain, M.L., Wasserman, S.A., Minorsky, P.V. ve Jackson, R.B. (2013). Campbell Biyoloji, (E. Gündüz, İ. Türkan, Çev.). Ankara, Palme Yayıncılık.

Sadava, D., Hillis, M.D., Heller, H.C. ve Berenbaum, M.R. (2014). Yaşam bilimi biyoloji. (E. Gündüz, İ. Türkan, Çev.). Ankara, Palme Yayıncılık.

Simon, E.J., Dickey, J.L., Hogan, K.A. ve Reece, J.B. (2017). Campbell temel biyoloji. (E. Gündüz, İ. Türkan, Çev.). Ankara, Palme Yayıncılı.

Smith, M.T. ve Smith, L.R. (2009). Elements of ecology, international edition, Pearson Benjamin Cummings, 649p, USA.

Solomon, E.P. (2003). Insan anatomisi ve fizyolojisine giriş. (L. B. Süzen, Çev.). İstanbul, Birol Yayıncılık.

Soong, B.C. ve Yager, R.E. (1993). The inclusion of STS material in the most frequently used secondary science textbook in the U.S. Journal of Research in Science Teaching, 30(4), 339-349.

Teiz, L. ve Zeiger, E. (2007). Bitki fizyolojisi. (E. Gündüz, İ. Türkan, Çev.). Ankara, Palme Yayıncılık.

Tekkaya, C. ve Balcı, S. (2003). Öğrencilerin fotosentez ve bitkilerde solunum konularındaki kavram yanılgılarının saptanması. Hacettepe Üniversitesi Eğitim Fakültesi Dergisi 24, 101-107.

Tekkaya, C., Çapa, Y. ve Yılmaz, Ö. (2000). Biyoloji öğretmen adaylarının genel biyoloji konularındaki kavram yanılgıları. Hacettepe Üniversitesi Eğitim Fakültesi Dergisi, 18, 140-147.

Toprak, T. (1993). İlkokul ders kitaplarının öğretim programına uygunluğunun değerlendirilmesi (Adana ilinde bir araştırma), Yayımlanmamış yüksek lisans tezi, Ankara Üniversitesi, Ankara.

Ünsal, Y. ve Güneş, B. (2003’a). İlköğretim 6. sınıf fen bilgisi ders kitabının fizik konuları yönünden incelenmesi. Gazi Üniversitesi Gazi Eğitim Fakültesi Dergisi, 23(3), 90-101.

Ünsal, Y. ve Günes, B. (2003b). Bir kitap inceleme çalısması örnegi olarak MEB ilkögretim 8. sınıf fen bilgisi ders kitabına fizik konuları yönünden elestirel bir bakıs. Gazi Üniversitesi Kastamonu Egitim Dergisi, 11(2).

Ünsal, Y. ve Güneş, B. (2002). Bir kitap inceleme çalışması örneği olarak MEB. İlköğretim 4. sınıf fen bilgisi ders kitabına fizik konuları yönünden eleştirel bir bakış, G. ̈. Gazi Eğitim Fakültesi Dergisi, 22(3) 110-120.

Victory, E. ve Kellough, R.D. (1997). Science for the elemantary and middle scho New Jersey: ol. Prientice Hal. İnc.

Wolf, M.K. ve Schave, B. (1984). Curriculum designing a handbook for educators. United States.

Yeniterzi, B. ve Işıksal-Bostan, M. (2015). An examination of the 7thgrade mathematics teacher's guidebook in terms of the relationship between mathematics and science. Elementary Education Online, 14(2), 407-420.

Yetişir, F., Salman, A. E., Özkardeş, A., Tokaç, M., Çiftçi, M. ve Kılıç, M. (2013). Conn sendromlu bir olguda başarılı laparoskopik korteks koruyucu adrenalektomi. Ulusal Cerrahi Dergisi, 29(1), 38-41. 